\title{
11
}

\section{COMMUNICATING FORENSIC GENETICS: 'ENTHUSIASTIC' PUBLICS AND THE MANAGEMENT OF EXPECTATIONS}

\author{
NINA AMELUNG, RAFAELA GRANJA \\ AND HELENA MACHADO
}

\subsection{INTRODUCTION}

'One of the most important problems in forensic medicine', write forensic geneticists Angel Carracedo and Lourdes Prieto, 'is the so-called "CSI effect"' (Carracedo \& Prieto 2018: 4). Their description of the threat posed by TV shows such as Crime Scene Investigation (CSI) to their discipline runs as follows: '[m]ost TV series present forensic evidence as infallible - one hundred percent reliable, with no margin for doubt when reality is very different: the scientific validity of forensic tests is variable' (ibid.). When looking at the communication of forensic science, we therefore seem to be confronted with an interesting paradox. While researchers and policy makers tend to complain about public disinterest in science and see this as threatening its cultural authority, in the case of forensic science we encounter the exact opposite. It is the prominence of forensic science in popular culture which seems to have raised expectations to a degree which might actually have negative consequences for the use of this knowledge in the context of criminal investigations and in the judicial system. 
Indeed, forensic genetics, as a specialisation of genetics and forensic science, is communicated and negotiated in particular settings. On the one hand, its identity is generally negotiated in and structured by the physical and social space of the forensic genetics laboratory, a space that is important in the chain of custody for producing DNA evidence that can be used for police criminal investigation and in the courtroom. On the other hand, the results of forensic genetic science are always eventually communicated in the courtroom, which becomes 'a theatre' (Felt and Davies, in Chapter 3, referring to Jasanoff) in which evidence needs to be demonstrated in a manner legible to the common sense of judges and jurors. In recent decades, public understandings of forensic genetics - publics including here also judges and police officers - have been understood as being strongly shaped by media representations in prominent TV series. As a consequence, forensic geneticists have had to reflect on the views of publics they encounter and to develop communication strategies to protect and defend their profession's identity, including the provision of guidance about 'good communication'.

In the present chapter we explore forensic geneticists' perceptions of how they carry out science communication to their specific publics in the criminal justice system. More particularly, we examine how forensic geneticists reconstruct their self-conception and relations to their publics when performing the presentation of DNA evidence in court. The research questions guiding our investigations are the following: What are the particularities of communicating forensic genetics? How do forensic geneticists cope with these particularities? And how do imaginaries of publics shape forensic geneticists' experiences of communication?

In what follows we will reflect on two strands of Science and Technology Studies (STS) debates that inform our study. After presenting our material and the methods we use, we present our analysis along three lines and draw concluding remarks.

\subsection{SCIENCE COMMUNICATION AS BOUNDARY-WORK: PROTECTING SCIENCE'S IDENTITY AND DELEGATING RESPONSIBILITIES}

Science communication scholars have highlighted that STS can offer relevant perspectives to understand how science and publics are co-produced in science communication practices (Davies \& Horst 2016: 204). Indeed, there is a quite large body of literature pointing to the fact that publics are not simply out there waiting to be informed about science, but are actively made through the precise settings and the spaces in which science communication happens (Felt \& Fochler 2010; Lezaun \& Soneryd 2007). In this context it is also useful to consider the distinction introduced by Mike Michael (2009) between 'publics-in-particular' namely specific, situated publics with identifiable stakes and interests - and 
'publics-in-general', a rather undifferentiated vision of 'people out there'. Thus, we have to consider that the criminal justice system, and in particular the courtroom, are specific spaces (see Chapter 3) in which forensic geneticists communicate about DNA evidence. This gives form to specific kinds of publics, and shapes the roles that can be taken on, how these are distributed, and the kinds of knowledge that can and need to be communicated.

We also suggest reading our case in the light of the dominant sense-making narratives used by science communication scholars and practitioners today, such as the so-called 'deficit model' (Davies \& Horst 2016: 37-39; Irwin 2014; McNeil 2013). The reference to the 'deficit model' usually serves as an established classification to describe certain ways of performing science communication (in particular one-way instead of two-way science communication; Davies \& Horst 2016: 37-39). This model has been used instrumentally, in the sense that it serves as a justification to argue for increasing scientific literacy or for excluding lay publics from some types of decision making. The 'deficit model' is thereby a manifestation of broader imaginations of what scientific governance should look like (Irwin \& Wynne 1996). In this chapter we will explore an additional, quite different, notion of the 'deficit model', applied not only to publics, but also to science/scientists. For our particular case, we will argue that the deficit model, as applied to science within forensic geneticists' discussions about science communication, serves as a gateway to renegotiate the responsibilities within forensic genetics and the use of forensic genetics' findings beyond its own communities.

Approaching science communication as relational and emergent also means paying attention to how imaginaries of publics prefigure science communication practices and to the role that communication plays in performing boundary-work (Gieryn 1983). Such boundary-work contributes on the one hand to maintaining the authority, credibility, and integrity of a specific scientific community (Jasanoff 1993, 2004), but on the other hand it also allows the performance of specific distributions of duties and responsibilities. As we will show, in this case, science is framed as being responsible for demonstrating the reliability and veracity of research results, while those who apply the results in the criminal justice system are presented as being responsible for the appropriate use of these results.

\subsection{DNA DOESN'T SPEAK - PEOPLE DO: COMMUNICATING DNA EVIDENCE IN THE CRIMINAL JUSTICE SYSTEM}

Particularly significant characteristics of forensic genetics derive from its specific epistemic culture (Cole 2013), which is distinct from other forensic science cultures as well as from science in general, and which impacts upon the particularities of communicating it. Forensic genetics differs from other 
forensic sciences by being celebrated as the 'gold standard' (Lynch 2003) among forensic sciences, suggesting a higher level of certainty and reliability due to its quantifiable estimations. Another important distinction comes from the type of work undertaken by forensic geneticists: these professionals tend to produce a specific type of scientific knowledge, designed to contribute to the investigation of a single criminal incident, and specifically to aid convictions or exonerations. Forensic genetic science's temporally limited nature within legal truth-finding processes thus comes from the specificity of knowledge claims and data produced (Cole 2013: 39).

Most relevant, in terms of impact on the particularities of communicating forensic genetics, is forensic geneticists' specific target audience, comprising police officers, prosecutors, judges, jurors - the so-called 'law-set' (Edmond 2001). The members of the criminal justice system that we will regard as forensic geneticists' publics-in-particular (Michael 2009) are specific and situated publics with identifiable stakes and interests in specific aspects of DNA evidence, which in turn helps them to fulfil their duties. By contrast, publicsin-general (Michael 2009) - or 'wider publics' as they are often referred to - are for most forensic geneticists an undifferentiated mass, who largely take their knowledge of forensic genetics from TV media.

One other particularity of communicating forensic genetics relates to how courts have emerged as democratising agents in disputes over the control and deployment of new DNA technologies, thereby advancing and sustaining a public dialogue about the limits of forensic genetics' expertise (Jasanoff 1995; Lynch \& Jasanoff 1998). Following the work of Michael Lynch and Sheila Jasanoff on that topic, a growing body of literature has addressed how the field of forensic genetics evolved and has been constructed through a complex series of practices and procedures that functioned to close down initial controversies and to guarantee the credibility and reliability of forensic DNA evidence in criminal justice systems worldwide (Aronson 2007; Derksen 2003; Lazer 2004; Lynch et al. 2008).

Although foundational controversies involving DNA evidence have been resolved, standardisation and legal acceptance does not mean the end of controversies surrounding the uses and interpretation of DNA evidence in court. Within the forensic genetics community, negotiations about diverse issues involving the uses and interpretation of DNA evidence mean that there is a continual need to seek common agreements in order to stabilise the field. Among these issues is a lack of protocol for dealing with diverse forms of reporting DNA evidence to non-experts (such as those found in courtrooms; Howes et al. 2014), and the challenges of communicating probabilistic results and likelihood ratios in typical identification cases (Amorim et al. 2016). Finally, the interpretation of complex DNA profiles, such as partial or mixed profiles, is also portrayed as being notably prone to reporting inconsistencies due to subjective decisions about whether a result is probative or inconclusive (Gill et al. 2008). 
STS literature on forensic genetics has also explored one other important dimension affecting the communication of DNA evidence in the criminal justice system: the so-called 'CSI effect', a concept employed by scholars, and increasingly also by practitioners and public media, to capture the assumption that members of the criminal justice system, and the public-in-general, confuse the idealised portrayal of DNA evidence on television with the actual capabilities of forensic genetics in the criminal justice system (Cole \& DiosoVilla 2009; Kruse 2010; Podlas 2009). The CSI effect, together with a lack of literacy on the probabilistic framework involved in the interpretation of DNA evidence, is considered by many forensic geneticists to be the major obstacle in their task of communicating the results of DNA analysis to members of the criminal justice system (Amorim 2012; Amorim et al. 2016). Although there is no consensus in social science studies about whether or not a CSI effect really does exist and what exactly it would consist of (see Ley et al. 2010), as we will show it is nevertheless an important element of forensic geneticists' narratives about the challenges of communicating forensic genetics analysis in courtrooms.

\subsection{METHODS}

This chapter draws on qualitative data derived from nine interviews conducted with forensic geneticists who work in forensic laboratories and/or university departments of forensic sciences based in different countries in Europe. Taking into consideration the diversity of the forensic genetics community (Cole 2013; Lynch et al. 2008), we adopted the following selection criteria to recruit participants in this study: they needed to hold a degree in disciplines directly connected to forensic genetics (Biology, Genetics and Medicine) and be the head of or employed by a forensic laboratory that provides DNA analysis for presentation as evidence in criminal cases. In line with Cole's proposal, our sample therefore aggregates forensic genetic scientists and research scientists (Cole 2013). Although the interview sample is small, for the purpose of pointing at the diverse argumentative repertoires that are the core interest of this chapter the diversity was large enough.

Recruitment was conducted by sending an invitation letter by email. Prior to the interviews, all the interviewees signed a written informed consent form and agreed to be audio-recorded. All the interviews were digitally recorded, transcribed verbatim, and anonymised. The script for the interviews covered the following themes: views and experiences of the expansion of criminal forensic DNA databases in different European jurisdictions, and of the transnational exchange of DNA data; opinions about the challenges of the uses of DNA technologies in the criminal justice system; perceptions on DNA technology development and innovation; and opinions about ethical issues and public engagement with forensic genetics. 
In order to avoid narrow framings of 'science communication' and 'public', for analysis purposes we use terms such as 'public(s)' but also others which appear to be used synonymously, such as 'citizens', 'collectives', 'lay groups', 'communities', 'society', or 'people'. Relevant quotations pertaining to the communication of DNA evidence were coded and subjected to multiple readings to develop in-depth understandings of prevalent notions of forensic genetic science communication and the relations between forensic genetics and society. These quotations were systematically compared, contrasted, synthesised, and coded by theme and by thematic category following the principles of grounded theory (Charmaz 2006), and interpreted using a qualitative content analysis approach (Mayring 2004).

\subsection{EMPIRICAL ANALYSIS}

\subsubsection{THE CSI EFFECT AND THE 'THREAT' OF ENTHUSIASTIC PUBLICS}

The particularities of communicating forensic genetics are understood by forensic geneticists as being shaped by the CSI effect and media coverage of high-profile cases, which they perceive as responsible for publics' beliefs in the alleged 'superior role' of DNA evidence (Lynch et al. 2008). This CSI effect is framed as having two interrelated consequences on publics. On the one hand, it has helped to foster public interest in forensic genetics, and to make citizens aware of the existence and evolution of DNA technologies. On the other hand, it disseminates exaggerated understandings of the alleged power of DNA to solve criminal cases. One of our interviewees explains this juxtaposition of implications:

The CSI effect has been significant, and the positive side of it is how young people have grown to be much more curious about the field. ... That's the good thing. The downside to CSI [effect] is presenting the tests as infallible, [as if it] always works.... [CO1]

Forensic geneticists thus accuse the media of providing an incomplete picture of DNA technologies. By exaggerating the possibilities, the speed, and the certainty of outcomes of DNA technologies, media narratives do not provide an adequate description of inherent limitations of genetic evidence: 'There is this famous CSI thing. But they [the publics] are not really educated about the pitfalls and limitations [of DNA evidence]' [O01]. Entertainment media narratives are represented as focusing on dramatic and emotionalised events in the portrayal of fictionalised representations of forensic science (Machado \& Santos 2011), standing in direct contrast to the efforts of accurately communicating 'sound science' (Hansen 2016). The emphasis on uncertainties in forensic geneticists' explanation of DNA evidence is framed as incompatible with 
mainstream forms of communication. As such, as noted by the following interviewee, forensic geneticists struggle with media representations of DNA evidence, which are portrayed as being assured facts:

[The main challenge of communicating science is] the information that people receive from television programs and the media and the sort of impression that science is about certainty: 'scientist says this and therefore it must be true' and, in fact, science is full of uncertainties. People do not understand that, they do not appreciate it. ... Uncertainties do not make good ... audience. [D09]

Consequently, forensic geneticists tend to portray their publics as overly 'enthusiastic' and as holding what they perceive to be unrealistic views about the possibilities of DNA technologies in criminal justice systems. However, these inflated perspectives on the potential contributions of DNA analysis to criminal investigation processes are not only present in forensic geneticists' views of lay publics, but also in framings of the publics-in-particular that are active members of the criminal justice system. Several of our interviewees outlined how police officers, prosecutors, and judges also attribute too much importance to DNA technologies when addressing criminal cases. In their opinion, DNA is generally considered to be 'a sort of priority type of evidence' [E01] which plays a decisive role in how criminal cases are presented in court:

This public perception is that if you have the DNA, that's it! That's all you need! And if you don't have the DNA, we'll have prosecutors [saying] 'You can't make a case with this, with no DNA!' [laughs]. [EO1]

Not being immune to representations that portray DNA as infallible, stakeholders directly involved in the criminal justice system are thus perceived as being strongly influenced by overly bright prospects fostered by the entertainment media: 'The CSI effect is a very common phenomenon, and therefore it shapes police officers' expectations about what is possible' [C04].

This poses several challenges to an adequate use of forensic genetic science in criminal investigations. Members of the criminal justice system are described as not being very well informed about the kind of information that can(not) be obtained from DNA technologies, and under what conditions such information can be retrieved. As a consequence, forensic geneticists often describe how they are confronted with frustration and disappointment on the part of members of the criminal justice system when they are unable to provide clear results - namely, a match or non-match - on the basis of a DNA profile:

It is so popular the perception that it [DNA] is infallible and there is a fairly substantial lack of scientific education in most inspectors who work with DNA. ... They will have either questions or issues with the results. ... You get back a mixed result, or a negative result, and they say 'We sent you a DNA analysis, so where is 
my result?' and we say 'Well, this is why we couldn't get a result', and they can't understand that. [E01]

The repercussions of overly positive expectations about the possibilities of DNA technologies are wide-ranging. A major concern, in the view of forensic geneticists, is that 'misrepresentations' might lead to miscarriages of justice, especially in cases where DNA technologies play a relevant role in deliberations in court. Forensic geneticists also voice their dissatisfaction with judges when the latter ignore the potential risks and the unintended consequences of overstating DNA evidence. One interviewee would put it as follows:

\begin{abstract}
Evidently, it [DNA evidence] is given much more importance by judges than it should. They must be aware that it's a clear mistake, they should be much more careful. ... Do judges know that $30 \%$ of incorrect rulings are linked to wrong identification of testimonies? Do judges know the real value behind each specific piece of scientific forensic evidence? They don't. And they make a barbaric number of mistakes because of that. [C05]
\end{abstract}

By pointing to a lack of knowledge among members of the criminal justice system and to the need to tackle their 'misconceptions', forensic geneticists engage in a standard 'deficit model' narrative. At the same time, they underline that this is a serious issue that touches on the shared responsibilities of members of the criminal justice system. Such a lack of awareness has potentially serious consequences, such as a possible miscarriage of justice. According to this view, one of the key types of DNA-related errors therefore results from misunderstanding the 'real value' of DNA evidence in court settings, rather than from errors that occur in the process of DNA analysis in the lab. Such a position also performs important boundary-work focused on constructing distinctions between the tasks of different professional groups in making use of DNA analysis: carrying out an analysis in the lab is the responsibility of forensic geneticists, while its final interpretation is the responsibility of judges in courts (Machado \& Granja 2018). According to forensic geneticists' views, the final (and therefore decisive) instance of interpretation of the evidence in order to reach a decision about guilt or innocence must be enacted by judges. As the following quotation illustrates, from such a perspective, forensic geneticists see their role as presenting and explaining DNA evidence, while also outlining the ambiguity involved in its interpretation:

I think that sometimes the expectation of the court [is] that they are going to be provided with some unambiguous scientific evidence of fact that is just going to allow them to come to the right conclusion in terms of guilt or innocence. I think there is a general difference in the perspective of the scientist, who will say: 'Well, we found this profile and it is up to the court to decide what its significance is, particularly in regard to the guilt or innocence of the accused person'. [D11] 
Forensic geneticists represent themselves as confronted by publics-in-particular that they feel have too strong expectations of DNA evidence, namely that it should provide a 'result' that forms a clear basis for deciding whether the accused is 'guilty' or 'innocent'. Members of the criminal justice system are regarded as having a specific 'deficit': one of being overly optimistic about the capacity of DNA analysis, which is seen as synonymous with their lack of scientific literacy for understanding the 'real value' and the probabilistic framework of DNA evidence. These forensic geneticists clearly subscribe to a 'deficit model', and with it to a particular vision of the publics-in-particular they encounter in the criminal justice system. This vision is instrumental in the sense that it reifies the boundary between the worlds of science and of non-science. On the one hand, their use of this 'deficit model' stabilises forensic genetics' authority over understanding DNA evidence; on the other hand, it constructs an enthusiastic, yet ignorant, public who have idealised views of DNA evidence, and thus who could potentially become a threat to the credibility of forensic genetics' epistemic authority (Marris 2015).

\subsubsection{BOUNDARY-WORK ALONG 'DEFICITS': ESTABLISHING RISK COMMUNICATION TO DELEGATE RESPONSIBILITY}

In order to cope with the particular challenges of communicating their work, forensic geneticists develop coping strategies within their epistemic community, strategies which attempt to counterbalance excessive expectations towards DNA technologies. Among these is the emergence of what can be called a 'proactive ethos of public responsibility' (Bliss 2012: 166-172; Machado \& Granja, 2018). This means that they aim to perform (forensic genetic) science in a way that is committed to and engaged with its wider social implications and the ways that its results are taken up in different arenas. One of the dimensions of this ethos is active communication of the limitations associated with DNA analysis within the criminal justice system, therefore deconstructing dominant visions that associate forensic science with a 'truth machine' (Lynch et al. 2008) that is able to provide certainty with regard to results. The adoption of such an idiom of uncertainty, one that addresses and attempts to manage the risks and uncertainties underlying forensic science, seems to have become part of the epistemic culture of forensic geneticists, as illustrated by the following quotation:

So, it is a question of trying to give as much genetic data as we can, but at the same time not offering a service that makes exaggerated claims about the accuracy or the precision of the tests from very small amounts of DNA. So, I think it is important that we are realistic about the limitations. [CO4]

Here we can detect a type of boundary-work that frames the identity of 'responsible' forensic genetics experts as characterised by a felt need to reflect 
on and clearly communicate the limitations of the evidence they can provide. Therefore, as a response to the high expectations present in the public arena, science communication is often preoccupied with caution concerning what forensic genetics cannot provide. Against the high expectations of its publics, the propagated approach for science communication here emphasises the responsibility for fully disclosing the limits and uncertainties, for example the deficits inherent to 'their science'. This is a new twist in applying a 'deficit model', this time to science (and scientists' responsibilities to cope with science's deficits).

A certain degree of formalisation and standardisation of such 'risk communication' has been established in protocols for using quantitative probabilistic value descriptions for reporting the results of DNA analysis when reaching out to members of the criminal justice system. Although being transparent about the limitations and risks of DNA results has become a routine part of reporting, it remains essential to make a distinction from 'messy' laboratory practices and to maintain the appearance of technical order (Lynch 2002) in producing evidence. The need to communicate that the uncertainties of DNA evidence are tamed and under control therefore also derives from the need to protect the epistemic community's credibility from becoming 'fodder for impeachment' (Cole 2013: 41) when exposed to potential fallibility. More recently, additional strategies for addressing such transparency-oriented approaches to risk communication have emerged. Some examples of this trend include providing concrete models for good practice for evaluative expert reporting and suggesting standards for evaluative reporting within professional networks, such as the European Network of Forensic Science Institutes (ENFSI) (Biedermann et al. 2017). According to several forensic geneticists, this type of risk communication is increasingly important as more sensitive methods of DNA analysis are being developed and, as a consequence, sensitivity to issues such as contamination has also risen (Gill et al. 2008). Some participants in our study therefore advocate the adoption of an even more careful strategy of interpretation and communication:

\footnotetext{
Now we are getting weak profiles, partial profiles, from contact stains, there may be secondary transfer, and all of these other things, and this also has to be taken into consideration for the interpretation of the evidence. And the awareness of this situation is not very widespread. This is something that we need to promote and to make public, that there are limits of testing that ... we are victims of our own success. ... Because we have made it [DNA technologies] very sensitive, and now we have to live with the consequences. [001]
}

Although some forensic geneticists might be committed to communicating the limitations and uncertainties of DNA analysis, judges and other members of the criminal justice system might not be willing to interpret, understand, engage with, or even accept such 'uncertain' premises. However, in 
the end, forensic geneticists partly delegate responsibility for managing the difficulties of interpreting DNA evidence to members of the criminal justice system. These types of tensions therefore illustrate the boundaries and tensions between the rationalities that guide the different epistemic cultures at work - those of science and the criminal justice system. This was addressed in the following quote:

In order to be successful in this interplay, of course we have the right to try to explain [DNA evidence], but the other guys, judges and lawyers, also have the duty of trying to understand. And unfortunately, as the society is organized, they prefer not to. Because the judges, most of them ... prefer that the DNA speaks for itself, they do not realise that they are deciding. And they go mad when I resist their pressing on me to state a probability or something like that. Which is misunderstanding everything I am trying to do. [NO1]

In adopting risk communication strategies anchored to policies of transparency, forensic geneticists thus attempt to leave the 'black box' of forensic evidence deliberately open, leaving uncertainty and the limitations of DNA technologies visible (Amorim 2012). However, this creates friction in as much as the intent of the criminal justice system - especially in decision-making spaces such as the courts - is to search for factual certainty in order to ensure that justice is done in each individual case (Jasanoff 2006), while the science system is quite used to handling a reasonable degree of uncertainty and error.

Besides delegating responsibility for interpreting DNA evidence to members of the criminal justice system, forensic geneticists also enact other kinds of boundary-work by defining what makes a good scientist (Machado \& Granja 2018) - that is, the one who communicates limitations - and delineating those who don't accept the same norms. Such individuals are framed as what Jasanoff (1993: 78) has called 'misfits, deviants, charlatans, or outsiders' to the enterprise of science. Several forensic geneticists demonstrate this pattern of othering 'bad behaviour', that is, attributing certain behaviours to colleagues who are seen as less committed to these norms of humility when it comes to the capacity of producing evidence with certainty. They are quite sceptical, doubting whether other colleagues stick to the ideal of communicating the limitations of DNA evidence:

When I am testifying in court I always try also to make clear where the limits of this evidence are. ... But I am not quite sure about my other colleagues. ... So basically, my impression is that there may be cases ... where the DNA was overstated, already in the report; there was no quality check because there was nobody in the court asking questions. Everyone just accepted that as a given fact, there was no criticism. [001]

Our findings suggest that these coping strategies of risk communication, and particularly the emphasis on limitations of forensic genetics' capacity to deliver 
unquestionable evidence, is not yet mainstream among forensic geneticists. It is, however, perceived as a reasonable approach to render the all-too-easily black-boxed aspects of uncertainty accompanying statistical interpretation of DNA evidence more explicit and visible (Amorim 2012; Biedermann et al. 2017). One way of stabilising the field of forensic genetics against criticism and keeping its authority is thus presented as the use of its own understanding of DNA evidence, with all its limitations made explicit, while delegating responsibility for binary decisions to other members of the criminal justice system.

\subsubsection{COMMUNICATING AND MOBILISING A FORENSIC GENETICS' UNDERSTANDING OF DNA EVIDENCE}

While the previously described coping strategies of forensic genetics mainly address how forensic geneticists redefine their self-conception and presentation of forensic genetics, this section explores how imaginaries of publics impact upon actual communication experiences with members of the criminal justice system. Most of the venues and material structures for communicating forensic genetics to publics-in-particular are pre-formatted by the criminal investigation and judicial settings. These routine practices entail, for instance, the production of written reports and the provision of expert testimony in courts at the request of judges or lawyers. Nevertheless, some forensic geneticists also use alternative spaces and formats to respond to what they perceive as being the needs of publics, for instance the need to clearly understand the potential and limitations of DNA evidence.

Based on the premise that members of the criminal justice system are not properly informed about forensic genetics and DNA evidence, many of our interviewees claim that there is a need for training designed to fill knowledge gaps, as the following quotation illustrates:

The investigators are often not the people who do the work in the laboratory and they may not have learned the same kind of knowledge. So, one of the problems is the collection of samples, for example, doing this properly. So there needs to be an educational program, which makes sure that everybody is aware of what they should be doing. [Q01]

By attempting to construct a shared knowledge base about DNA analysis, forensic geneticists take on the role of public educators. In doing so, they are therefore delineating hierarchies of knowledge, attempting to assure their epistemic authority (i.e., their role as experts), protecting the autonomy of forensic genetics, and creating new forms of scientific legitimation and consolidation of expertise claims (Gieryn 1983; Kruse 2016).

The narratives of most of the forensic geneticists we interviewed highlighted the belief that, by occasionally engaging with members of the criminal justice 
system through educational courses and direct interactions - at least in more exceptional criminal cases, they might reduce the overall risk of potential misinterpretation of certain DNA evidence. This is illustrated by the following quotation:

I think it is important to educate the police officers about your own work.... We are doing it because we are offering educational workshops, trainings, where we invite police to give them an update about our work. ... Normally [when] we are involved in a major case, like a capital crime, then we have direct contact with ... police officers. They like this very much because they can come to our institute and then we can discuss the case, and we can demonstrate what we have found and what it means. [001]

When addressing publics-in-particular, forensic geneticists thus occasionally attempt to actively engage them in training, education, and joint discussion. Such moments enrich forensic geneticists' imaginaries of their publics by giving them access to the needs of publics-in-particular, as articulated by those publics themselves. They further provide an opportunity to actively share forensic geneticists' understanding of DNA evidence, thereby somewhat (re)distributing responsibility for (correctly) interpreting DNA evidence.

However, the willingness of forensic geneticists to engage directly with their publics-in-particular remains limited. Entertainment media is generally understood as limiting their capacity to reach out to wider publics and to influence exaggerated views about the potential of DNA technologies. In this sense, although forensic geneticists acknowledge the need to provide education and information, some may in fact contribute to the power of the CSI effect by overlooking the influence of their own claims to shape public opinion. Feeling unable to compete with media impact on audiences, some forensic geneticists end up demonstrating a certain resignation about challenging dominant perceptions:

And we need to make improvements, and all roads lead to education and information. I worry about living in a world where everything is part of the news, not a world where we value education, instead everything becomes breaking news, everything ends up on newspapers or television. It's all CSI. But where's the education? [C05]

Beyond communication experiences with members of the criminal justice system, publics-in-general are, at least to a certain extent, perceived as being 'out of reach': 'We are interested in public perception, but it is not as important to us as police perception' [C04]. Consequently, forensic geneticists tend to give priority to communication with their publics-in-particular, who are in principle the greater threat to the credibility of forensic genetics. 


\subsection{CONCLUSION}

This chapter has addressed the particularities of communicating forensic genetics and shown how forensic geneticists respond to these particularities. It has also elaborated on forensic geneticists' imaginaries of public audiences, and how these imaginaries shape their experiences of communication.

Forensic geneticists feel that the conditions under which they communicate DNA evidence in the criminal justice system are shaped by widely shared media representations of the capacities of DNA technologies. These representations are understood as being beyond their control, producing considerable 'misconceptions' among both publics-in-particular and publics-in-general. Consequently, confronted with what they describe as overly 'enthusiastic publics', communication of forensic genetics is frequently framed by a deficit model approach. Forensic geneticists' imaginaries of their publics-in-particular judges, the police, or jury members - not only highlight their lack of knowledge, but also construct them as a potential threat to forensic expertise. Public misunderstanding of the nature of DNA evidence is framed as potentially putting into jeopardy both the credibility of forensic genetics and, ultimately, the ability of the criminal justice system to deliver justice.

As we have described, forensic geneticists develop coping strategies to manage these challenges. They emphasise the need to communicate the limitations of forensic genetics, and particularly the potential risks and uncertainties in the interpretation of quantitative probabilistic frameworks for forensic DNA analysis. They also point to the fact that interpretation frameworks can differ substantially: binary conventions of interpretation inherent in the criminal justice system are very different from the interpretation principles prevalent among forensic geneticists. Importantly, forensic geneticists work to (re)align the distribution of responsibility for the interpretation of DNA evidence. While they suggest that it is the responsibility of (good) forensic geneticists to highlight the contingencies of DNA evidence, and that of other parts of the criminal justice system to make final judgements concerning justice, they also propose educational initiatives for their publics-in-particular. Again, work is done here to outline the boundaries between the practices of forensic geneticists and members of the criminal justice system in the interpretation of DNA evidence and judicial decision making.

This case thus offers us an unusual approach to science communication: that of stressing science's limitations. This invites us to apply the deficit model in a new way. Studying the communication of forensic genetics means investigating a case in which the deficit not only applies to publics, but is applied by scientists to science itself (and other scientists). This emphasis on deficiencies becomes constitutive of a communication strategy for responding to what is perceived by the science community as 'too enthusiastic publics'. As such, this case study might reveal insights relevant to other situations where publics may be too 'enthusiastic', for instance in the context of 'breakthrough' 
medical knowledge, or space science imagined as realising utopian dreams of life beyond the Earth.

While the deficit model of publics is instrumental in the sense that it serves as a justification to argue for increasing scientific literacy or for excluding lay publics from some types of decision making, the deficit model, as it is here applied to science, serves as a gateway to renegotiate responsibilities for the non-trustworthy and illegitimate use of scientific findings. In the case of forensic genetics, the misuse of scientific findings may turn into miscarriages of justice. Therefore, when forensic geneticists emphasise the need to take the process of appropriately interpreting scientific results for criminal investigation purposes or judicial decisions seriously, at the same time they underline the fact that the responsibility to interpret all evidence so as to reach decisions - about investigative strategies, or about guilt or innocence lies beyond the boundaries of the responsibility of forensic geneticists.

Forensic geneticists thus aim to renegotiate the meanings of forensic genetics that circulate in the courtroom and beyond. They seek to deconstruct the notions about DNA technologies conveyed by the media and to clarify the contingencies of DNA evidence. Forensic geneticists reaffirm what has been called the 'CSI effect' in relation to publics-in-particular present in the courtroom. Yet interestingly, the reference to 'the CSI effect' barely even refers to the television programme anymore. Instead, it has become a sense-making category for forensic geneticists to delineate any understanding of DNA evidence that is different from their own - and thereby a tool to create a unified identity for forensic geneticists.

\section{ACKNOWLEDGEMENTS}

This work received funding from the European Research Council (ERC) under the European Union's Horizon 2020 research and innovation programme (grant agreement No. 648608), within the project 'EXCHANGE - Forensic geneticists and the transnational exchange of DNA data in the EU: Engaging science with social control, citizenship and democracy', led by Helena Machado and currently hosted at the Communication and Society Research Centre (CECS), Institute for Social Sciences of the University of Minho, Portugal. The authors are extremely grateful for comments received from Ulrike Felt and Sarah Davies and an additional anonymous reviewer.

\section{REFERENCES}

Amorim, António. 2012. 'Opening the DNA Black Box: Demythologizing Forensic Genetics'. New Genetics and Society 31 (3): 259-270. doi:10.1080/14636778.2012.6 87083. 
Amorim, António, Manuel Crespillo, Juan Luque, Lourdes Prieto, Oscar Garcia, Leonor Gusmão, Mercedes Aler, Pedro Barrio, Victor Saragoni, and Nadia Pinto. 2016. 'Formulation and Communication of Evaluative Forensic Science Expert Opinion-A GHEP-ISFG Contribution to the Establishment of Standards'. Forensic Science International: Genetics 25: 210-213. doi:10.1016/j.fsigen.2016.09.003.

Aronson, Jay. 2007. Genetic Witness: Science, Law, and Controversy in the Making of DNA Profiling. Piscataway, NJ: Rutgers University Press.

Biedermann, Alex, Christophe Champod, and Sheila Willis. 2017. 'Development of European Standards for Evaluative Reporting in Forensic Science: The Gap between Intentions and Perceptions'. The International Journal of Evidence \& Proof 21 (1-2): 14-29. doi:10.1177/1365712716674796.

Bliss, Catherine. 2012. Race Decoded: The Genomic Fight for Social Justice. Stanford, CA: Stanford University Press.

Carracedo, Ángel, and Lourdes Prieto. 2018. 'Beyond the CSI Effect: Keys for Good Forensic Genetics Communication'. Mètode Revista de Difusió de La Investigació 9 (June). doi:10.7203/metode.9.10628.

Charmaz, Kathy. 2006. Constructing Grounded Theory: A Practical Guide through Qualitative Analysis. Thousand Oaks, CA: Sage.

Cole, Simon. 2013. 'Forensic Culture as Epistemic Culture: The Sociology of Forensic Science'. Studies in History and Philosophy of Biological and Biomedical Sciences 44 (1): 36-46. doi:10.1016/j.shpsc.2012.09.003.

Cole, Simon, and Rachel Dioso-Villa. 2009. 'Investigating the "CSI Effect" Effect: Media and Litigation Crisis in Criminal Law'. Stanford Law Review 61 (6): 1335-13374.

Davies, Sarah R., and Maja Horst. 2016. Science Communication: Culture, Identity and Citizenship. London: Palgrave Macmillan. doi:10.1177/1075547009339048.

Derksen, Linda. 2003. 'Agency and Structure in the History of DNA Profiling: The Stabilization and Standardization of a New Technology'. University of California, San Diego. www.academia.edu/1407355/Agency_and_structure_in_the_history_of_ DNA_profiling_The_stabilization_and_standardization_of_a_new_technology.

Edmond, Gary. 2001. 'The Law-Set: The Legal-Scientific Production of Medical Propriety'. Science, Technology, \& Human Values 26 (2): 191-226. doi:10.1177/016224390102600204.

Felt, Ulrike, and Maximilian Fochler. 2010. 'Machineries for Making Publics: Inscribing and De-Scribing Publics in Public Engagement'. Minerva 48 (3): 219-238. doi:10.1007/s11024-010-9155-x.

Gieryn, Thomas F. 1983. 'Boundary-Work and the Demarcation of Science from NonScience: Strains and Interests in Professional Ideologies of Scientists'. American Sociological Review 48 (6): 781-795.

Gill, Peter, James Curran, Cedric Neumann, Amanda Kirkham, Tim Clayton, Jonathan Whitaker, and Jim Lambert. 2008. 'Interpretation of Complex DNA Profiles Using Empirical Models and a Method to Measure Their Robustness'. Forensic Science International: Genetics 2 (2): 91-103. doi:10.1016/j. fsigen.2007.10.160.

Hansen, Anders. 2016. 'The Changing Uses of Accuracy in Science Communication'. Public Understanding of Science 25 (7): 760-774. doi:10.1177/0963662516636303.

Howes, Loene M., Roberta Julian, Sally F. Kelty, Nenagh Kemp, and K. Paul Kirkbride. 2014. 'The Readability of Expert Reports for Non-Scientist Report-Users: Reports 
of DNA Analysis'. Forensic Science International 237 (April): 7-18. doi:10.1016/j. forsciint.2014.01.007.

Irwin, Alan. 2014. 'From Deficit to Democracy (Re-Visited)'. Public Understanding of Science 23 (1): 71-76. doi:10.1177/0963662513510646.

Irwin, Alan, and B. Wynne. 1996. Misunderstanding Science: Public Reconstructions of Science and Technology. New York: Cambridge University Press.

Jasanoff, Sheila. 1993. 'What Judges Should Know about the Sociology of Science'. Jurimetrics Journal 77 (2): 77-82. http://heinonline.org/HOL/Page?handle=hein. journals/juraba32\&id=357\&div=\&collection=journals\%5Cnhttp://www. heinonline.org/HOL/Page?handle=hein.journals/juraba32\&id=357\&collection=jou rnals\&index=journals/juraba.

Jasanoff, Sheila. 1995. Science at the Bar: Law, Science, and Technology in America. Cambridge, MA, and London: Harvard University Press.

Jasanoff, Sheila. 2004. States of Knowledge: The Co-Production of Science and Social Order. Abingdon and New York: Routledge. doi:10.4324/9780203413845.

Jasanoff, Sheila. 2006. 'Just Evidence: The Limits of Science in the Legal Process'. Journal of Law, Medicine \& Ethics 34 (2): 328-341. doi:10.1111/j.1748720X.2006.00038.x.

Kruse, Corinna. 2010. 'Producing Absolute Truth: CSI Science as Wishful Thinking'. American Anthropologist 112 (1): 79-91. doi:10.1111/j.15481433.2009.01198.x.

Kruse, Corinna. 2016. The Social Life of Forensic Evidence. Oakland, CA: University of California Press.

Lazer, David (ed.). 2004. DNA and the Criminal Justice System: The Technology of Justice. Cambridge, MA: The MIT Press.

Ley, Barbara L., Natalie Jankowski, and Paul R. Brewer. 2010. 'Investigating CSI: Portrayals of DNA Testing on a Forensic Crime Show and Their Potential Effects'. Public Understanding of Science 21 (1): 51-67. doi:10.1177/0963662510367571.

Lezaun, J., and L. Soneryd. 2007. 'Consulting Citizens: Technologies of Elicitation and the Mobility of Publics'. Public Understanding of Science 16 (3): 279.

Lynch, Michael. 2002. 'Protocols, Practices, and the Reproduction of Technique in Molecular Biology'. British Journal of Sociology 53 (2): 203-220. doi:10.1080/00071310220133304.

Lynch, Michael. 2003. 'God's Signature: DNA Profiling, the New Gold Standard in Forensic Science'. Endeavour 27 (2): 93-97.

Lynch, Michael, Simon A. Cole, Ruth McNally, and Kathleen Jordan. 2008. Truth Machine: The Contentious History of DNA Fingerprinting. Chicago, IL: University of Chicago Press.

Lynch, Michael, and Sheila Jasanoff. 1998. 'Contested Identities: Science, Law and Forensic Practice'. Social Studies of Science 28 (5-6): 675-686. doi:10.1177/030631298028005001.

Machado, Helena, and Rafaela Granja. 2018. 'Ethics in Transnational Forensic DNA Data Exchange in the EU: Constructing Boundaries and Managing Controversies'. Science as Culture 27 (2): 242-264.

Machado, Helena, and Filipe Santos. 2011. 'Popular Press and Forensic Genetics in Portugal: Expectations and Disappointments Regarding Two Cases of Missing Children'. Public Understanding of Science 20 (3): 303-318. doi:10.1177/0963662509336710. 
Marris, Claire. 2015. 'The Construction of Imaginaries of the Public as a Threat to Synthetic Biology'. Science as Culture 24 (1): 83-98. doi:10.1080/09505431.2014.98 6320.

Mayring, Philipp. 2004. 'Qualitative Content Analysis'. In Uwe Flick, Ernst von Kardorff, and Ines Steinke (eds.), A Companion to Qualitative Research, pp. 266-269. London: Sage.

McNeil, Maureen. 2013. 'Between a Rock and a Hard Place: The Deficit Model, the Diffusion Model and Publics in STS'. Science as Culture 22 (4): 589-608. doi:10.1080 /14636778.2013.764068.

Michael, Mike. 2009. 'Publics Performing Publics: Of PiGs, PiPs and Politics'. Public Understanding of Science 18 (5): 617-631. doi:10.1177/0963662508098581.

Podlas, Kimberlianne. 2009. 'The "CSI Effect" and Other Forensic Fictions'. Loyola of Los Angeles Entertainment Law Review 27: 87-125. 